\title{
Constraints to Vegetable Production Resulting from Pest and Diseases Induced by Climate Change and Globalization: A Review
}

\author{
Mutondwa M. Phophi ${ }^{1} \&$ Paramu L. Mafongoya ${ }^{1}$ \\ ${ }^{1}$ Department of Crop Science, School of Agricultural, Earth and Environmental Sciences, University of \\ KwaZulu-Natal, Scottsville, Pietermaritzburg, South Africa \\ Correspondence: Department of Crop Science, School of Agricultural, Earth and Environmental Sciences, \\ University of KwaZulu-Natal, Private Bag X01, Scottsville, 3209, Pietermaritzburg, South Africa. E-mail: \\ mutondiwa@gmail.com
}

Received: July 1, 2017

doi:10.5539/jas.v9n10p11
Accepted: August 9, $2017 \quad$ Online Published: September 15, 2017

URL: https://doi.org/10.5539/jas.v9n10p11

\begin{abstract}
Vegetable production worldwide is constrained by pests and diseases which effects are exacerbated by climate change and variability. Greenhouse gas emissions are also increasing due to poor agricultural practices and other human activities. This will continue to have a negative impact on the prevalence of insect pests and diseases. This review focuses on the climatic factors that impact on insect pests and diseases of vegetable crops. High atmospheric temperatures and elevated carbon dioxide increases pest development, survival of pests and distribution of pest to new areas. The distribution of insect pests and diseases are not due to climate changes only but are also a result of globalisation and poor biosecurity measures at country borders. There is limited information on the distribution of pests and diseases due to globalisation in African countries. New exotic pests will continue to be introduced to countries if biosecurity measures are not improved. Future research must focus on how to manage emerging pests and diseases influenced by high temperatures and carbon dioxide and other climatic conditions which influence pest severity under smallholder farmers in the southern African regions.
\end{abstract}

Keywords: biosecurity, emerging pests, insect pest management, smallholder farmers

\section{Introduction}

More undernourished people are found in African regions and this has remained a great challenge in the Sub-Saharan Africa (FAO, 2015). South Asia and Sub-Saharan Africa constitutes at least one billion of people who suffer from malnutrition, lacking carbohydrates, vitamins, and other micro-nutrients (Keatinge et al., 2011). Smallholder farmers do not only grow vegetables for income purposes but also for improvement of human nutrition at household level. Vegetables are rich in essential micro-nutrients such as vitamin A, C, E, zinc, copper, iron and antioxidants (Afari-Sefa et al., 2016). FAO (2004) recommends that a human being needs to consume $200 \mathrm{~g}$ of vegetables per day. However, vegetable consumption is still below $200 \mathrm{~g}$ per day especially for the poor and this results in the rising rates of malnutrition (Keatinge et al., 2011).

The major common constraints to vegetable production in smallholder farmers are pests and diseases and these limits farmers in obtaining better crop yield and ensuring food security. Some smallholder farmers have adopted the use of chemicals to manage insect pests and diseases in vegetable production. However, there is a challenge of insect resistance that is building up and this is becoming a constraint to insect pest management and obtaining good crop yields (Jallow et al., 2017). The overuse of pesticides is also leading to health problems and impacting the environment when not handled properly. Jallow et al. (2017) indicated that $65 \%$ of farmers agreed that the use of chemicals for insect management is hazardous to the environment and $70.5 \%$ confirmed that pesticides can be dangerous to human health. This will remain a huge problem to farmers who depend on chemicals to manage insect pests, especially when climate change is having an impact on the biology and distribution of insect pests.

\section{Greenhouse Gas Emissions}

The increase of greenhouse gas emissions resulting from human activities and other natural factors has become a world-wide threat impacting the environment through climate change. These activities include the use of fuels 
and deforestation and are contributing to the elevation of carbon dioxide and increase of temperatures (Olabemiwo et al., 2017). Carbon dioxide contributes 58.8\% greenhouse gasses (Olabemiwo et al., 2017).

Agricultural practices can also contribute to the emission of greenhouse gases when carbon dioxide is being released. Carbon dioxide can be released through burning of plant materials and also through decomposition of soil organic matter (Kang \& Banga, 2013). These emissions of greenhouse gasses are expected to increase because human population is increasing and it depends on agriculture for food (Kang \& Banga, 2013). The use of fertiliser in crops also contributes to greenhouse gas emissions. Nitrous oxide can be emitted through the use of nitrogen fertilisers. Farmers can find other alternatives of fertilising their crops with less emissions of greenhouse gasses.

\section{Climate Variability}

Extreme weather events such as heavy rainfalls leading to floods, severe droughts and extreme heat waves have been increasing since the past decades and are still expected to increase in the next few decades to come (Mirza, 2011). These processes will continue to have implications on agricultural productivity on a global scale (Gornall et al., 2010). Climate change is most likely to alter insect pests and the relationship between the host and insect can be affected (Bale et al., 2002) thus resulting in negative impact on crop productivity. Some crops which are known to be resistant to insect pest can become susceptible and react positively to pest damage under the influence of climate change and global warming (Reddy, 2013).

Climate change and global warming can result in observable changes to insect pest life such as migration of insect pest and invasion to other areas, increase in geographical range of insects, and influencing the population of insect pests by increasing their rate of development and cycles within a short period of time (Reddy, 2013). All these changes resulting from climate change can contribute to difficulty to predict the effect of pest management and this can result in low crop yields. Also a one year change of climate can influence pest outbreaks and if the pests are aggressive enough, there can be a regime shift of insect pests (Kiritani, 2013). Insect pests that are most affected by climate change and global warming are those that are ectothermic because they can quickly acclimatize to different environmental conditions. This gives them an advantage to multiply aggressively, increasing their threat to crop production (Ferrer et al., 2014). Examples of insect pests that easily adapt to high temperatures include, aphids, whitefly and stem borers (Sharma, 2014).

Increased temperatures and elevated atmospheric carbon dioxide are the most conspicuous factors of climate change that have become a threat to crop production (Mendelsohn, 2008). These two factors have been increasing and are still predicted to increase by the end of twenty-first century (Trebick et al., 2015). The two factors have resulted in shifts of pests from lower latitudes to higher latitudes (Barzman et al., 2015) and also altered insect pest pressures negatively through emerging pests and positively through migration, thus creating consequences to the environment and to crop productivity (Ziska \& McConnell, 2016).

\section{Impact of Temperature on Insects and Disease}

Global warming exerts extensive effects on insect life and the terrestrial ecosystem and it is still predicted to cause major changes in the near future. Temperature increase has been predicted to elevate by $3.4{ }^{\circ} \mathrm{C}$ by the end of twenty-first century (Barzman et al., 2015). With all these predictions, vegetable production in dryland areas will continue to be vulnerable to these temperature effects (Macfadyen et al., 2016). Policy makers can be able to make use of these predictions to make suitable policies for farmers on management strategies of mitigation and adaptation to pests impacting crop production (Sharma \& Prabhakar, 2014). Global warming can affect insect population in a number of ways such as: changes in population growth rate, the increase in number of insect generations, the extension of geographical range, the introduction of species to alternative host plants, the increase of invasion risk by migrating insects and also overwintering of insects (Bale et al., 2002; Maran \& Pelini, 2016).

High temperatures can alter the growth and development of insects affecting the fecundity and mortality of insects (Khaliq et al., 2014). The increase in insect population numbers occurs when the growth and developmental rate has been speed up. For example short living insects that have adapted to high temperatures can be able to increase the number of generations in a year when influenced by warmer conditions (Van Dyck et al., 2014). Meisner et al. (2014) showed that higher temperatures increased aphid (Aphidius ervi) growth and developmental rate and also increased the span of adult life under $20^{\circ} \mathrm{C}$ and $27{ }^{\circ} \mathrm{C}$. This means that the higher the developmental rate, the more the insect cycles and the higher the population size. This can result in more severe damage to crops if farmers are failing to control insect pests. 
Different stages in the life cycle of an insect can respond differently to high temperatures (Zhang et al., 2015). Some insects can be highly favoured by high temperatures, influencing their population positively, whereas some insects can result to high mortality rates under high temperatures. Diamondback moth (Putella xylostella) has been monitored under high temperatures and it was reported that its growth and development was affected by temperature. Egg production and the adult stage of this insect were decreased at higher temperatures. However, the larval stage was found to be highly tolerant to high temperatures (Zhang et al., 2015). This means that there could be implications when managing this insect pest under high temperatures in the near future. Aphidius ervi found in peas was found to be tolerant when monitored in high temperatures. High temperatures influenced the an increase in the developmental rates of this aphid and the adult stage was found to be more tolerant to high temperatures thus resulting in increased rates of pea damage (Meisner et al., 2014).

Most insects have the potential for long distance mobility and flight. High temperatures can increase the mobility of some insects as well as their distribution. Most insects usually move to the northern regions were they are able to disappear from unsuitable climatic conditions (Ziska et al., 2013; Pulator et al., 2016). Most of these insects that have high rates of migration are ectotherms and this type of insects is expected to continue shifting to higher latitudes and altitudes in the next decades (Vanhanen et al., 2007). It has been predicted that insects will shift by $6.1 \mathrm{~km}$ to the upward poles per decade due to increased temperatures (Parmesan \& Yohe, 2003). In the UK, the lepidopteran moths and butterflies have been reported each year to have increased in migration rate and this has been linked to increased temperatures in the south west Europe (Sparks et al., 2007). Grapholita molesta (Busck), a lepidopterian moth has the potential to adapt to high temperature environment and has been found to have good flying abilities under high temperature (Ferrer et al., 2014). In Africa, smallholder farmers are most likely to be vulnerable to this factor because severe high temperatures are predicted to be experienced in African areas (Biber-Freudenberger et al., 2016). Tuta absoluta, Ceratitis cosyra and Bactrocera invadens are the most common insects pests found in Africa and they have been recorded to increase their suitability to different types of environment across the African continent (Biber-Freudenberger et al., 2016). The advantage to habitat suitability by insect pest can influence the increase of the ability to spread and acclimatize to different environments while at the same time causing damage to crops.

High winter temperatures can affect and also influence the presence and outbreaks of insect pest (Reddy et al., 2015). Warmer winters can result to reduction in mortality rates of insect pests and this often leads to high infestations on crops thus increasing the damage and yield loss (Harrington et al., 2001). Warmer winters can also increase the distribution of insect pests because of reduced mortality rates (Battisti et al., 2005). The African bollworm (Herlicoverpa amigera) is regarded as one of the major insect pest in agricultural production. This insect has the ability to overwinter due to increased temperatures in winter season (Reddy et al., 2015). The southern green stink bug (Nezara viridula): heteroptra: pentatomidae) showed a high survival rate in winter season due to increased warmer conditions (Musolin et al., 2009). It can be expected that due to high temperatures, warmer seasons can be long and therefore resulting to warm winter conditions which can result to high presence of insect pest.

Temperature, light and water are the main factors that control and influence the development of plant diseases, their survival, the rate of multiplication and the rate at which inoculums disperse and penetrate on plants, spreading the diseases on plants (Ahanger et al., 2013). Increased temperatures influence the growth and development of most plant pathogens. Pathogens that depend on temperature for development can be active due to high temperature, and if utilising the warmer conditions, they can develop and start spreading on crops if left uncontrolled (Ahanger et al., 2013). Most plant pathogens that have a short life cycle may reproduce rapidly and have a high distribution rate when exposed to higher temperatures (Coakley et al., 1999). When temperatures are high, pathogens can migrate to new areas where there are potential susceptible hosts that can influence the development of diseases (Etterson \& Shaw, 2001). Plants that grow in the tropics are the ones that are usually affected by diseases that are influenced by high temperatures. This is because these plants have got a narrow temperature growth range and they are quick to respond positively to temperature changes (Ghini et al., 2011). Late blight diseases have been recorded in the earlier ages to be aggressive at $10-25{ }^{\circ} \mathrm{C}$ temperatures. However, recently these diseases have now adapted to higher temperatures of up to $27{ }^{\circ} \mathrm{C}$ (Luck et al., 2011). Due to predictions of increasing temperatures in this century, pathogens are most likely to be found in large numbers and resulting in difficulties in controlling them.

High temperatures can influence the development and spread of stem rust caused by Puccinia graminis $f$. sp tritici (Gautam et al., 2013). Stem rust has been reported to be more aggressive when temperatures are high and it has shown to be quick in adapting to high temperature changes (Mboup et al., 2012). Bacteria such as Rasoltonia solanacearum was also reported that it grows and develops rapidly due to high temperatures. High 
temperatures with low rainfall can also influence the spread of viruses such as Maize dwarf mosaic virus and Beet yellow virus (Clover at al., 1999; Olson et al., 1990). The severity of these diseases will affect smallholder farmers because of high vulnerability to climatic changes and also lack of knowledge to manage diseases.

\section{Extreme Weather Events}

Climate change can result in extreme weather events that can have an impact in agricultural production and insect pests and diseases (Adamo et al., 2012). These extreme events include long periods of drought spells, long spells of heavy rainfall and extreme high temperatures (Rosenzweig et al., 2001). The long spells of high temperatures and drought are linked to El Nino scenarios (Rosenzweig et al., 2001). Long dry spells and drought can enhance insect population growth rates and reproduction rates (Adamo et al., 2012). Pests found in the temperate regions are predicted to be more affected by extreme weather events. They are predicted to increase in population during long dry spells (Adamo et al., 2012). A study was done in South Africa on some of the problematic fruit flies (Ceratitis capitata) commonly known as the medfly and C. rosa commonly known as the Natal fruit fly. These fruit flies showed an increase in their abundance due to extreme high temperatures. However their fecundity rates showed to decrease in low temperatures (Nyamukondiwa et al., 2013). The lower temperatures in the Western Cape province of South Africa can have an influence in reducing the effectiveness of these flies, therefore high rates of mortality and less damage to the fruits (Nyamukondiwa et al., 2013).

Heavy rainfalls affect insect biology and survival negatively. Most insects are vulnerable to heavy rainfall, thus affecting their growth development and population (Pellegrino et al., 2013). Heavy rainfall can result to increased mortality rates of insects (Pellegrino et al., 2013). A study was done and showed that heavy rainfalls can result to high rates of locust mortality. Heavy rainfalls affected the locusts eggs and the nymph survival was reduced severely (Woodman, 2015).

Extreme weather events can result to insect pest outbreaks (Ju et al., 2013). These outbreaks can wipe out crop species due to severe damage and spread of diseases. They can also influence invasion of alien pest species that may have an impact in crop yield (Kannan \& James, 2009). However invasion of new species due to extreme events will also depend on whether the insect is adapting well to the new environment and climatic conditions (Sharma, 2014).

Frequent heavy rainfall can influence the spread of pathogens and fungal diseases. Many plant pathogens are known to respond positively when there is rainfall (Thompson et al., 2013). Plant pathogens such as Phytophthora cinnamomi and Botryosphaeria doithidea are amongst the many pathogens that are known to respond positively when there is rainfall (Thompson et al., 2013).

\section{Impact of Elevated Carbon Dioxide on Insects and Diseases}

Presently, the level of atmospheric carbon dioxide is $400 \mu \mathrm{mol}^{-1}$ and it is predicted to potentially increase by the end of $21^{\text {st }}$ century to $650 \mu_{\mathrm{mol}^{-1}}$ (Trebecki et al., 2015; Vassiliadis et al., 2016). Most studies have been done on the impact of carbon dioxide on crop plants but little is known about atmospheric carbon dioxide on plant insect pests and diseases. Carbon dioxide can affect plant growth and development by altering the physiology and morphology of the plant. Such alterations induced by carbon dioxide can affect the diet quality and feeding behaviour of insects (Ryan et al., 2014). Although these alterations affect the feeding behaviour of insects, these insects are affected differently. Elevated carbon dioxide was found to have an impact in the lepidopteran Herlicoverpa amigera. The feeding behaviour of the larvae was affected by elevated carbon dioxide. Results showed that elevated carbon dioxide contributed to the increase of food consumption and metabolism of the larvae and this gives an indication that Helicoverpa amigera larvae may cause more damage under elevated carbon dioxide (Akbar et al., 2016). Herlicoverpa amigera is one of the major global insect pest that feed on brassicas and its damage can lead to high yield loss (Machekano et al., 2017). The ability of this insect pest to cause damage can be highly influenced by climatic changes (Machekano et al., 2017). Sucking insects such as aphids can also be affected by elevated carbon dioxide (Newman, 2003). Some studies show an increase in aphid population due to elevated carbon dioxide (Newman, 2003). However, some plants can produce defensive compounds which can affect the feeding, development and survival of sucking insect pests (War et al., 2012).

Elevated concentrations of carbon dioxide are most likely to affect the pressure of insect pest in both managed and unmanaged crops. These pressures from insect pests can either be in a form migration to new areas or they can be in a form of new introduction in areas (Ziska et al., 2016), and these often underlies their distribution and abundance, hence the level of damage they cause to crops (Mazzi \& Dion, 2012). Elevated concentrations of carbon dioxide also affect insect pest growth and their development and this often results in changes in the interaction between insect pests and their crop host (Akbar et al., 2016; Elad \& Pertot, 2014). 
Carbon dioxide also has an impact on plant diseases. Carbon dioxide influences the growth and development of the crops, crop canopy and the microclimate as well as the quantity of tissues susceptible to diseases (Pannga et al., 2013). The canopy microclimate can influence the presence, survival and dispersal of plant pathogens (Pannga et al., 2013).

Elevated carbon dioxide may result in extreme changes of reproduction, spread and severity of plant diseases and this is a threat to food security (Gautam et al., 2013). Plant diseases can result from bacteria, fungi and viruses and their interaction with plants can be highly influenced by weather patterns including elevated carbon dioxide (Nopsa et al., 2014). A range of foliar diseases can be encouraged by dense canopies due to increased carbon dioxide. Such foliar diseases that are influenced by elevated carbon dioxide include powdery mildew, rust, leaf spots and also blights and these diseases are known to develop in warm weather conditions (Gautum et al., 2013). Diseases such as late blight (Phytopthora infestans) known to infect potatoes, blast (Pyricularia oryzae) and sheath blight (Rhizoctonia solani) known to infect rice are known to cause significant damage to these crops, hence more threat under elevated carbon dioxide (Gautam et al., 2013).

\section{Impact of Globalisation on Spread of Insect Pests and Diseases}

Alien species can impact crop production in countries and this can lead to economic crop yield loss (Saccaggi et al., 2016). Alien species are defined as species that have the ability to live and adapt outside their natural habitat (Sujay et al., 2010). Alien species can occur in the form of insect pests, fungal diseases, viruses and other species that are also non-agricultural (Sujay et al., 2010). Most of these alien pests have the ability to outcompete native pests because they can highly adapt to new environments. They have aggressive growth and reproduction and they can move long distances at the same time spreading and causing damage to agricultural crops (Rejmanek \& Richardson, 2000). The risk of these alien pests have been increasing and has become a great threat to agricultural production, especially insect pests such as arthropods due to their small size and high ability to tolerate different climatic conditions (Saccaggi et al., 2016).

Alien pest species can be introduced to the country intentionally or unintentionally. Alien pests can be introduced by movement of people and goods from one country to the other, through imports of agricultural products such as fruits, vegetables, seeds (Hulme et al., 2008) and propagation materials (Saccaggi et al., 2026). Improvement of logistic has recently resulted in the ease of commodities to be exported to different countries globally, this has been found to influence the introduction of alien pests through contamination (Hulme, 2009). The increase of transport networks, both aquatic and terrestrial, is also playing a role in the introduction of pests to other countries (Hulme, 2009). The magnitude and the level of distribution of these alien pests on agricultural products between countries is still not well understood (Paini et al., 2016). However, it is said that the most countries to suffer from invasions by alien species are the sub-Saharan countries and also those countries that receive large volumes of agricultural imports (Paini et al., 2016).

\section{Phytosanitary Measures}

Biosecurity measures are taken to reduce the introduction of alien pest species in countries (Cope et al., 2016). Biosecurity includes phytosanitary measures which are conducted at the country borders. Detection of alien species are conducted whereby travellers, machines, luggage and food are inspected for hidden pests (Liebhold et al., 2006). Other methods of detection include vacuuming travellers' goods to remove small or unseen particles such as seeds and insects, preventing their entry into foreign countries (Fortune, 2006). Small insect pests are not easy to detect at the border when biosecurity measures are taken (Saccaggi et al., 2016). This becomes a problem when small insect pests with high reproductive rates pass through the border and adapt to the foreign environment. These pests then result to high damage to crop production. Some alien pests are able to enter foreign countries due to poor biosecurity measures (Caley et al., 2015). Insect pests that belong to order coleoptera, hemiptera, lepidoptera and diptera have been entering Australia during the years of 1986-2005. These pests have been recorded all these years because the biosecurity measures has been poorly facilitated, therefore increasing high rates of invasion and damage from these pests (Caley et al., 2015). To develop effective biosecurity measures, policy makers need to understand the sources of these alien pests and diseases and their rate of distribution and how they adapt to different environmental conditions and also the damage they can cause of agricultural products (Bourdot et al., 2012). As indicated previously, most alien pests are introduced as contaminants, there will be an increase of challenges to policy makers and the management of these pests. There is a need to monitor the trends in which alien species are being introduced in foreign countries and the biosecurity measures should be regulated more effectively to reduce the entry of alien pest (Hulme et al., 2008). 


\section{The Role of Vegetables in Human Nutrition}

The amount and types of nutrients consumed by human beings daily can affect the human's nutritional status. The lack of good nutrition in human diet may result in serious health conditions which can affect the lifestyle of humans in future (Keatinge et al., 2011). Malnutrition conditions are very common in young children especially those in the sub-Saharan African countries (Brown \& Pollitt, 1996). Lack of nutrition in children can affect the development of brains (Brown \& Pollitt, 1996). However this damage can be reversed if proper nutrients are consumed (Brown \& Pollitt, 1996). A diet with high fat and sugar result in poor development and reduction of IQ in children (Northstone et al., 2011). High consumption of foods with protein, vitamins can result in better chances of increasing the children's IQ (Northstone et al., 2011). Nutrition is also very important for pregnant women and for women who are in the reproductive era. Foods that contain vitamins, minerals and folate are highly essential for preventing foetal damage in pregnant women (FAO/WHO, 2004). There is nutrition transition in the west African countries such as Ghana and Senegal (Bosu, 2015). There is high consumption of sugar and fatty foods leading to increasing rates of obesity by $115 \%$ since 2004 in the west African countries with less consumption of vegetables and fruits (Bosu, 2015). Studies have shown that there is increased rate of hypertension in Burkina Faso and Cape Verde due to lack of good nutrition consumption (Busu, 2015). Lack of vitamin has been reported in 250,000 to 500,000 African children, resulting to blindness every year and half of the kids dying within 12 months of their blindness (WHO, 2013). Iron is another essential nutrient that has been reported to be deficient in the sub-Saharan countries, resulting to health consequences (WHO, 2002). There are still 2 billion people who are undernourished in African countries and this has increased malnutrition problems because food demand is higher than the food supplied (FAO, 2013). The nutrition transition in African countries does not only affect human beings in higher socioeconomic strata, but it also affects the poor and the uneducated who are already affected by poor sanitation and other diseases (Busu, 2015).

Vegetable consumption is the first important step to overcome human malnutrition, especially to those who are more vulnerable to lack of nutrients (Yang \& Keding, 2009). Vegetables are very important for reducing malnutrition problems in human beings (Ojiewo et al., 2015). Most vegetables which contain essential nutrients include cabbages, tomatoes, black nightshade, cowpea and soybeans. These vegetables contain nutrients such as vitamin $\mathrm{A}$, vitamin $\mathrm{E}$, protein, iron, folate, zinc and calcium which are very essential for human diet (FAO/WHO, 2004). Vegetables can be made available to households when grown in home gardens. There is need to increase vegetable production for human beings to obtain essential micronutrients through their diets (Ojiewo et al., 2015) The green revolution concentrated on staple crops such as maize, wheat, rice and cassava to eliminate poverty in the African regions. However, these crops do not contain essential micro-nutrients (Ojiewo et al., 2015). Tenkouano (2011) suggested that these crops rather constitute to "grain revolution" than "green revolution" due to lack of micro-nutrients. Vegetables and legumes contains essential micro-nutrients and needs to be part of a well-balanced diet and has to be included as part of the green revolution (Tenkouano, 2011).

\section{Traditional Vegetables}

Traditional vegetables can also be consumed to combat malnutrition problems. These types of vegetables are not usually grown and supplied on a large scale (Mampholo et al., 2016). However, they can be grown and sold locally with less management and can tolerate adverse weather conditions. Most of these vegetables are redroot pigweed (Amaranthus retroflexus), mustard spinach and black nightshade (Solanum nigrum) and are most consumed in South Africa (Mampholo et al., 2016). Traditional vegetables are rich in calcium, zinc, vitamin A, B, E, and other antioxidant compounds (Yang et al., 2009). Absence of these nutrients in the human diet can result to what is called "hidden hunger" and other chronic diseases (Yang \& Keding, 2009). Black nightshade contains compounds such as flavonoids, ascorbic acid, protein, vitamins and other minerals such as calcium, potassium and phosphorus (Van Averbeke et al., 2007). Consumption of these vegetables can help to alleviate poverty and food insecurity in rural households (Van Averrbeke et al., 2007). Solanum nigrum also contains high levels of zinc and magnesium (Uusiku et al., 2010). All these vegetables are very common in the Limpopo Province and continuous provision of these vegetables can help reduce malnutrition in households, at the same time reducing food insecurity and making income when sold to markets. However, the constraints in growing these vegetables include lack of quality seeds, varieties, shortage of water, pests and disease infestation and also lack of information on markets (TsChirlea et al., 2004).

\section{Major Insect Pests of Vegetables Grown in South Africa}

Most of these insect pests that causes damage to vegetables include bagrada bug (Bagrada hilaris), diamondback moth (Putella xylostella), and aphids. 
Bagrada bug (Bagrada hilaris) commonly known as painted bug is a native pest in most countries including African countries. This bug is known to have originated in Asia (Halbert \& Eger, 2010). Bagrada bug commonly feeds on crucifer's crops and brassica crops such as cabbages, mustard, kale and other brassica crops (Bundy et al., 2012). It has also been reported to feed on crops of other families such as Zea mays L., Sorhgum bicolor (L.) sunflower (Helianthus annuus) and cotton (Gossypium hirsutum) in the United States (Reed et al., 2011). Bagrada bug is considered as one of the major serious pests resulting to huge threats in vegetable production (Huang et al., 2014). It has been reported for the first time in Los Angeles County, Carlifornia and Anzona in 2008 (Palumbo \& Natwick, 2010). This bug has been found to have increased its distribution to native countries including African countries. It has been reported in countries such as Zimbabwe (Grzywackz et al., 2010), Botwsana (Obopile et al., 2008), South Africa, Mozambique, Kenya and Tanzania (Infonet-Biovision, 2015). However little is known about the host preferences of bagrada bug (Huang et al., 2014) and there is little understanding of bagrada bug distribution and damage in South Africa.

Bagrada bug is a sucking insect with piercing mouthparts. Bagrada bug takes 41 days to complete its entire life cycle in conducive environments of warmer climate (Reed et al., 2013). After eclosion, female bugs become receptive to the male bug in 1-2 days and it takes 4-5 days for oviposition to occur after mating for the first time (Singh \& Malik, 1993). This pests can lay 100-200 eggs underside of the leaves, stem or on loose soil. However, this pest does not lay eggs in large numbers like other insect pests, it lays eggs singly or in groups of 10 eggs (Reed et al., 2013). It can overwinter in soil cracks to escape cold weather conditions which are not good for its survival (Reed et al., 2013).

This insect is usually triggered by high temperatures for effective activity. High temperatures influences the walking and mating of bagrada bug (Huang et al., 2013). A study was done in feeding of bagrada bug and results suggested that this pest feeds effectively on brassica crops in the afternoon and evening when temperatures are high (Huang et al., 2013).

Bagrada bug can be found feeding from crop seedling to maturity stage (Divya et al., 2015; Patel et al., 2017). Studies have shown that bagrada bug can invade in newly emerging crops and causing damage to the apical meristem of the crops (Palumbo \& Natwick, 2010; Huang et al., 2014). This bug uses a lacerate and flush feeding method (Hori, 2000). During feeding on crops, bagrada bug secrete saliva enzymes which results in crop damage (Reed et al., 2013). Bagrada bug also removes cell sap from the plant tissues of brassica and non-brassica crops, resulting in crop deterioration (Banuelos et al., 2013). Excessive feeding on apical meristem of vegetables can result in poor head/crown formation in cabbages and this becomes a consequence of poor marketable cabbages (Palumbo \& Natwick, 2010). It may also result to death of growing plant tip and deformation of adventitious budding (Reed et al., 2013). Damage caused by bagrada bug can lead to death of plants (Huang et al., 2014). Adult or mature crops can result to malformation of leaves and circular scorching of leaves due to damage caused by bagrada bug (Reed et al., 2013). However young susceptible crops normally show signs of wilting and death of tissues leading to death of the plant (Reed et al., 2013). Leaves of young susceptible crops can show white spots as a result of feeding by bagrada bug (Patel et al., 2017).

Diamondback moth is also one of the major global insect pests than can result to huge crop loss. It is commonly known to feed on brassica crops such as cabbages (Machekano et al., 2017). Diamondback moth is said to be ubiquitous and it can survive throughout the whole year, feeding and resulting to crop damage (Furlong et al., 2013). This insect pest has certain factors that give it the ability to cause severe damage to crops if left uncontrolled. It has high potential of reproduction, ability to distribute and migrate to other areas, it has the ability to adapt easily to different environmental conditions, and it has high ability to reproduce throughout the whole year remaining abundant and difficult to manage (Canico et al., 2013; Furlong et al., 2013). Diamondback moth has been reported in African countries such as Kenya, South Africa, Malawi, Mozambique, Zambia, Namibia, Zimbabwe and Botswana (APR, 2015). Brassica export to African countries is still in great demand although there is high incidence of Diamondback moth. South Africa is one of the countries that has great exportation of brassicas to neighbouring countries such as Mozambique, Angola, Lesotho and Swaziland (DAFF, 2015). However this pest has been found to be a constraint in the quality of brassica crops in South Africa, and therefore this results to poor marketable products (Furlong et al., 2013). Southern African countries will continue to be vulnerable to climate change (IPCC, 2014), and this will be problematic to brassica production because diamondback moth is exacerbated by climatic changes and variability (Furlong et al., 2013). In countries such as China, diamondback moth has costed the Chinese economy about US\$0.77 billion annually (Li et al., 2016). 


\section{Farmers' Control Methods}

Most farmers use chemical method to manage diamondback moth. Research suggests that most small scale farmers in Southern African countries rely on insecticides to manage DBM. Countries such as Mozambique has $100 \%$ reliance on chemical control (Camico et al., 2013) and Botswana has $98 \%$ reliance on chemical control for this pest (Obopile et al., 2008), while Zambia and Namibia has about $70 \%$ reliance of chemical control (Nyirenda et al., 2011). These farmers have been found to apply insecticides at different rates and at different frequencies (Canico et al., 2013). Research has shown that most farmers in these Africa countries are applying insecticides once every three weeks to control diamondback moth. However, due to high population of this pest, farmers end up applying insecticides three times a week (Obopile et al., 2008). Such application results in insect resistance development especially if chemicals of the same mode of action are applied, therefore also causing implications in management of this pest. This type of application can also result to environmental contamination. Some farmers are applying a mixture of different chemical ingredients to control diamondback moth. However it has been recorded that most of these farmers are doing this without any guidance from the manufacturer and therefore it becomes harmful to the environment (Ngowi et al., 2007). Diamondback moth has also been reported to be resistance to many insecticides in China ( $\mathrm{Li}$ et al., 2016). Integrated Pest Management has been proved to be effective in reducing diamondback moth in China. China country has made more efforts to support implementation of Integrated Pest Management and this has been adopted by many farmers. However, these practices need to be supported continuously to prevent more insecticide reliance by farmers ( $\mathrm{Li}$ et al., 2016).

According to the reviewed, there is little information reported on these pests in South Africa. There is a need to address the impact of climatic changes especially high temperatures on the survival and population of emerging pest in smallholder farmers. Most research has been conducted in commercial farmers and little is known with regards to smallholder farmers and their management of these pests.

\section{The Use of Companion Crops for Insect Pest Management}

The use of companion crops is one of the ecological practices for smallholder farmers who don't have resources to manage insect pests that are damaging their main crops (Calumpang \& Navasero, 2013). The main purpose of growing companion crops is to protect main crops from insect pests that will cause damage and therefore resulting in high yield loss. Companion crops can be grown as trap crops or intercrops and this can be referred to as the push-pull strategy. Companion crops grown as intercrops attracts insect pests, making insect pests less attractive to main crops and this is known as the "Push" (Cook et al., 2007). Companion crops grown as trap crops ensures that insect pests that may feed on main crops are reduced in numbers. This is referred to as the "Pull" (Cook et al., 2007). Companion crops grown as trap crops are usually grown around field crops (Khan et al., 2001). Napier grass (Pennisetum purpureum Schumach) is one of the companion crops grown around maize crop field. This grass can attract maize stem borer while reducing chances of attacking maize crops (Khan et al., 2014).

Companion crops grown as intercrops can be used as repellents for insect pests (Finch \& Collier, 2011). The idea of these repellents is to release volatile chemical compounds that can deter insect pests. Insect pests are able to detect repellent companion crops from a distance away from the plant and this can cause the pest to stay away from the crop thus reducing damage to the main crops (Finch \& Collier, 2011). Some of the crops that can be grown to repel insect pest are eggplant (Solanum melongena L.), lemon grass (Cymbopogon citratus Stapf) and marigold (Tagetes erecta L.) (Calumpang \& Navasero, 2013). A study was conducted to repel corn borer using eggplant and lemon grass as repellents. Results showed that the growth rate and damage caused by corn borer was reduced. Companion crops can be artificial. These artificial crops are meant to disrupt the visual pest processes and to interfere with the host selection process by the pest (George et al., 2013). Maize can be intercropped with desmodium (Desmodium uncinatum Jacq DC) as a companion crop to repel stem borer moths in maize crops. It can repel stem borer moths and it also has the ability to attract natural enemies of this insect pest (Khan et al., 2014).

Companion crops can be grown for more than one purpose at the same time. It can be grown to repel insect pests and also to improve soil fertility. For example desmodium spp crop can repel insect pests of maize at the same time it can be used to improve soil fertility through biological nitrogen fixation and organic matter improvement (Khan et al., 2014).

It is always a challenge to decide on which companion crops can be effective to manage insect pest. It is of importance for farmers to know different companion crops which are effective before planting them. Companion crops should be tolerant to drought if crop production is to be practiced in arid and semi-arid areas. These crops 
should also be resilient to moisture stress since erratic rainfall and unpredictable rainfall patterns are expected due to climatic changes (Khan et al., 2014).

There are few studies done on companion crops for pest management, most of them have focused on field crops such as maize, sorghum and millet. Very few studies have looked on companion crops for vegetable pest management. There is very limited knowledge of herbs used as companion crops for management of insect pests on vegetable production. More studies have done trap crops to attract insect pest. Very little is known about herbs that can be used to repel insect pests of vegetables through the odour they produce. There are few studies conducted in South Africa under smallholder farmers that produce vegetables on companion crops. Therefore there is a need for smallholder farmers who cannot afford insecticides to make use of this practice to manage pests and to reduce insecticide application on their vegetable crops. This will also help to suppress the rate of chemical resistance influenced by frequent insecticide application.

\section{Areas of New Research}

Most studies were conducted in temperate countries. Very few studies have been done in Africa. High temperature in South Africa must be evaluated on its effects on new and emerging pests. Modelling techniques must be used to predict the spread of new and emerging pests in South African provinces. More studies should also be done on farmer's perceptions on new and emerging pests and how it interacts with climate change and variability. Studies must be done on invasive species entering southern African countries and South Africa through globalisation, trade, plants, and plant products. Regional, national and global networks should work on new and emerging pests for efficient use of resources in addressing this $21^{\text {st }}$ century challenge.

\section{Conclusion}

This review has concluded that anthropogenic activities and some agricultural practices such as pesticide application and burning of fuels do influence greenhouse emissions resulting to climatic changes. Climate change and variability such as increased temperatures and levels of carbon dioxide can result in changes in the biology of an insect. This can increase mortality rates, fecundity rates, growth and development of insects and adaptation and distribution of insects to new areas. However this depends on the type of insects and the conditions which are conducive for development. It is concluded that insect pests such as diamondback moth, bagrada bug and aphids will continue to adapt well in warmer conditions and their distribution rate towards the North Pole will be high due to the fact that they respond very well to high temperatures. It is expected that these pests will result to extreme crop damage in warmer areas if they are left uncontrolled due to increased generations and populations. It can also be expected that these pests may have high overwintering rates if temperatures continue to be high. More research has been conducted on climate change and its effect on crop yield. More research should focus on how ectothermic pests and other emerging pests should be managed when influenced by climatic changes.

The distribution of insect pests and diseases does not only result from climatic changes. Globalisation also plays a huge role in distributing native pests to countries. This review showed that the South African countries are expected to be more vulnerable to introduction of new pests and diseases due to poor biosecurity measures. Research should focus on long term monitoring of insect pest and diseases. New efficient strategies should therefore be introduced at the borders to limit the introduction of native pests to countries. More research has focused on the European countries. However, little is known on the introduction of new pests and diseases in the Southern African countries. This gives an indication that government should provide funding for better biosecurity measures.

\section{Acknowledgements}

The study is supported by National Research Foundation through the South African Research Chair: Agronomy and Rural Development at the University of KwaZulu-Natal, in South Africa.

\section{References}

Adamo, S. A., Baker, J. L., Lovett, M. M. E., \& Wilson, G. (2012). Climate change and temperate zone insects: The tyranny of thermodynamics meets the world of limited resources. Environmental Entomology, 41, 1644-1652. https://doi.org/10.1603/EN11188

Afari-Sefa, V., Rajendran, S., Kessy, R. F., Karanja, D. K., Musebe, R., Samali, S., \& Makaranga, M. (2016). Impact of nutritional perceptions of traditional African vegetables on farm household production decisions: A case study of smallholders in Tanzania. Experimental Agriculture, 52, 300-313. https://doi.org/10.1017/ S0014479715000101 
Ahanger, R. A., Bhat, H. A., Bhat, T. A., Ganie, S. A., Lone, A. A., Wani, I. A., .. Bhat, T. A. (2013). Impact of climate change on plant diseases. International Journal of Modern Plant and Animal Sciences, 1, $105-115$

Akbar, S. M., Pavani, T., Nagaraja, T., \& Sharma, H. C. (2016). Influence of $\mathrm{co}_{2}$ and temperature on metabolism and development of Herlicoverpa amigera (Noctuidae: Lepidoptera). Environmental Entomology, 45, 229-236. https://doi.org/10.1093/ee/nvv144

Arthropod Pesticide Resistance Database (IRAC). (2015). Michigan State University. Retrieved from http://www.pesticideresistance.com/display

Bale, J. S., Masters, G. J., Hodkinson, I. D., Awmack, C., Bezemer, T. M., Brown, V. K., ... Whittaker, J. H. (2002). Herbivory in global climate change research: Direct effects of rising temperature on insect herbivores. Global Change, 8, 1-16. https://doi.org/10.1046/j.1365-2486.2002.00451

Banuelos, G. S., Dhillon, K. S., \& Banga, S. S. (2013). Oilseed brassicas in biofuel Crops. In B. P Singh (Ed.), Production Physiology and Genetics (pp. 339-368). https://doi.org/10.1079/9781845938857.0339

Barzman, M., Lamichhane, J. R., Booij, K., Boonekamp, P., Desneux, N., Huber, L., ... Messean, A. (2015). Research and priorities in the face of climate change and rapidly evolving pest. Sustainable Agriculture Reviews, 17, 1-27. https://doi.org/10.1007/978-3-319-16742-8_1

Biber-Freudenberger, L., Ziemacki, J., Tonnang, H. Z., \& Borgemeister, C. (2016). Future risks of pest species under changing climatic conditions. PLOS ONE, 11(4), e0153237. https://doi.org/10.1371/journal.pone. 0153237

Bourdot, G. W., Lamoureaux, S. L., Watt, M. S., \& Kriticos, D. J. (2012). The potential global distribution of the invasive weed Nasella neesiana under current and future climates. Biological Invasions, 14, 1545-1556. https://doi.org/10.1007/s10530-010-9905-6

Brown, J. L., \& Pollitt, E. (1996). Malnutrition, poverty and intellectual development. Scientific American, 247, 38-43. https://doi.org/10.1038/scientificamerican0296-38

Bosu, W. K. (2015). An overview of the nutrition transition in West Africa: Implications for non-communicable diseases. Proceedings of the Nutrition Society, 74, 466-477. https://doi.org/10.1017/ S0029665114001669

Bundy, C. S., Grasswitz, T. R., \& Sutherland, C. (2012). First report of the invasive stink bug Bagrada hilaris (Burmeister) (Heteropter: Pentatomidae) from New Mexico, with notes on its biology. Society of Southwestern Entomologists, 37, 411-414. https://doi.org/10.3958/059.037.0317

Caley, P., Ingram, R., \& DeBarro, P. (2015). Entry of exotic insects into Australia: Does border interception count match incursion risk? Biological Invasions, 17, 1087-1094. http://doi.org/10.1007/s10530-014-0777-z

Calumpang, S. M. F., \& Navasero, M. V. (2013). Behavioural response of the Asian corn borer Ostrinia furnacalis Guenee (Lepidoptera: Pyralidae) and the earwig Euborelia annulipes Lucas (Dermaptera: Anisolabiidae) to selected crops and weeds associated with sweet corn. Philippine Agricultural Scientist, 96, 48-54.

Canico, A., Santos, L., \& Massing, R. (2013). Development and adult longevity of diamondback moth and its parasitoids Cotesia plutellae and Diadegma semiclausum in uncontrolled conditions. African Crop Science Conference Proceedings, 11, 257-262.

Clover, G. R. G., Smith, H. G., Azam-Ali, S. N., \& Jaggard, K. W. (1999). The effects of drought on sugar beet growth in isolation and in combination with beet yellow virus infection. Journal of Agricultural Science, 133, 251-161. https://doi.org/10.1017/S0021859699007005

Coakley, S. M., Scherm, S., \& Chakraborty, S. (1999). Climate change and disease management. Annual Review of Phytopathology, 37, 399-426. http://doi.org/10.1146/annurev.phyto.37.1.399

Cook, S. M., Khan, Z. R., \& Pickett, J. A. (2007). The use of push-pull strategies in integrated pest management. Annual Review of Entomology, 52, 375-400. https://doi.org/10.1146/annurev.ento.52.110 405.091407

Cope, R. C., Ross, J. V., Wittmann, T. A., Prowse, T. A. A., \& Cassey, P. (2016). Integrative analyses of the physical transport network in Australia. PLOS ONE, 11, 0148831. https://doi.org/10.1371/journal.pone. 0148831 
DAFF. (2015). A profile of the South African cabbage market value chain: Department of Agriculture, Forestry and Fisheries. Acardia, South Africa. http://www.nda.agric.za

Elad, Y., \& Pertot, I. (2014). Climate change impacts on plant pathogens and plant diseases. Journal of Crop Improvement, 28, 99-139. https://doi.org/10.1080/15427528.2014.865412

FAO. (2004). FAO STAT. Food and Agriculture Organisation, Rome, Italy. Retrieved from http://www.fao.org

FAO. (2013). The state of food insecurity in the world 2013. The multiple dimensions of food security. Rome, Italy. Retrieved from http://www.fao.org

FAO. (2015). The state of food insecurity in the world 2014. Rome: Food and Agriculture Organisation of the United Nations. Retrieved from http://www.fao.org

FAO/WHO. (2004). Vitamin and mineral requirements in human nutrition. Food and Agricultural Organisation, Rome. Retrieved from http://www.fao.org

Ferrer, A., Mazzi, D., \& Dorn, S. (2014). Stay cool, travel far: Cold-acclimated oriental fruit moth females have enhanced flight performance but lay fewer eggs. Entomologia Experimentils et Applicata, 151, 11-18. https://doi.org/10.1111/eea.12163

Finch, S., \& Collier, R. H. (2011). The influence of host and non-host companion plants on the behaviour of pest insects in field crops. Entomologia Experimentalis et Applicata, 142, 87-96. https://doi.org/10.1111/ j.1570-7458.2011.01191.x

Fortune, A. L. (2006). Biosecurity at the extreme: Pathways and vectors between New Zealand and Scott Base, Antarctica (M.Sc. thesis, University of Canterbury, Canterbury, NZ). Retrieved from http://citeseerx.ist. psu.edu

Furlong, M. J., Wright, D. J., \& Dosdall, L. M. (2013). Diamondback moth ecology and management: Problems, progress and prospects. Annals Review of Entomology, 58, 517-554. https://doi.org/10.1146/ annurev-ento-120811-153605

Gautam, H. R., Bhardwaj, M. L., \& Kumar, R. (2013). Climate change and its impact on plant diseases. Current Science, 105, 1685-1691.

George, D. R., Collier, R. H., \& Whitehouse, D. M. (2013). Can imitation companion planting interfere with host selection by Brassica pest insects? Agricultural and Forest Entomology, 15, 106-109. https://doi.org/ 10.1111/j.1461-9563.2012.00598.x

Ghini, R., Bettiol, W., \& Hamada, E. (2011). Disease in tropical and plantation crops as affected by climate changes: Current knowledge and perspectives. Plant Pathology, 6, 122-132. https://doi.org/10.1111/j.13653059.2010.02403.x

Gornall, J., Betts, R., Burke, E., Clark, R., Camp, J, Willett, K., \& Wiltshire, A. (2010). Implications of climate change for agricultural productivity in the early twenty-first century. Philosophical Transactions of The Royal Society B, 365, 2973-2989. https://doi.org/10.1098/rstb.2010.0158

Grzywacz, D., Rossbach, A., Rauf, A., Russell, D. A., Srinivasan, R., \& Shelton, A. M. (2010). Current control methods for diamondback moth and other Brassica insect pests and the prospects for improved management with lepidopteran-resistant Bt vegetable brassicas in Asia and Africa. Crop Protection, 29, 68-79. https://doi.org/10.1016/j.cropro.2009.08.009

Halbert, S. E., \& Eger, J. E. (2010). Bagrada bug (Bagrada hilaris) (Hemiptera: Pentatomidiae) an exotic pest of the cruciferae established in the Western USA. http://www.freshfromflorida.com/pi/pest_alerts/pdf/ bagrada-bugpest-alert.pdf

Harrington, R., Fleming, R. A., \& Woiwod, I. P. (2001). Climate change impacts on insect management and conservation in temperate regions: Can they be predicted? Agricultural and Forestry Entomology, 3, 233-240. https://doi.org/10.1046/j.1461-9555.2001.00120

Hori, K. (2000). Possible causes of disease symptoms resulting from the feeding of phytophagous Heteroptera. In C. W. Schaeter \& A. R. Panizzi (Eds.), Heteroptera of Economic Importance (pp. 10-35). CRC Press. https://doi.org/10.1201/9781420041859.ch2

Huang, T.-I., Reed, D. A., Perring, T. M., \& Palumbo, J. C. (2013). Diel activity and behaviour of Bagrada hilaris (Hemiptera; pentatomidae) on dessert cole crops. Horticultural Entomology, 106, 1726-1738. 
Huang, T.-I., Reed, D. A., Perring, T. M., \& Palumbo, J. C. (2014). Host selection behaviour of Bagrada hilaris (Hemiptera: pentatomidae) on commercial cruciferous host plants. Crop Protection, 59, 7-13. https://doi.org/10.1016/j.cropro.2014.01.007

Hulme, P. E., Bacher, S., Kenis, M., Klotz, S., Kühn, I., Minchin, D., ... Vilà, M. (2008). Grasping at the routes of biological invasions: A framework for integrating pathways into policy. Journal of Applied Ecology, 45, 403-414. https://doi.org/10.1111/j.1365-2664.2007.01442.x

Hulme, P. E. (2009). Trade, transport and trouble: Managing invasive species pathways in an era of globalization. Journal of Applied Ecology, 46, 10-18. https://doi.org/10.1111/j.1365-2664.2008.01600.x

Infonet-Biovision. (2015). Bagrada bug. Zurich. Retrieved from http://infonet-biovision.org/node/28470

Intergovernmental Panel on Climate Change (IPCC). (2014). Climate Change 2014: Synthesis Report. Fifth Assessment Report (AR5), Contribution of Working Groups I, II and III to the Fifth Assessment Report of the Intergovernmental Panel on Climate Change. IPCC: Geneva, Switzerland. https://doi.org/ 10.1017/CBO9781107415416

Jallow, M. F. A., Awadh, D. G., Albaho, M. S., Devi, V. Y., \& Thomas, B. M. (2017). Pesticide risk behaviours and factors influencing pesticide use among farmers in Kuwait. Science of the Total Environment, 574, 490-498. https://doi.org/10.1016/j.scitotenv.2016.09.085

Ju, H., Vander Velde, M., Lin, E., Xiong, W., \& Li, Y. (2013). The impacts of climate change on agricultural production systems in China. Climate Change, 120, 313-324. http://doi.org/10.1007/s10584-013-0803-7

Kang, M. S., \& Bang, S. S. (2013). Global agriculture and climate change. Journal of Crop Improvement, 27, 667-692. https://doi.org/10.1080/15427528.2013.845051

Kannan, R., \& James, D. A. (2009). Effects of climate change on global diversity: A review of key literature. Tropical Ecology, 50, 31-39

Keatinge, J. D. H., Yang, R. Y., Hughes, J., Easdown, W. J., \& Holmer, R. (2011). The importance of vegetables in ensuring both food and nutritional security in attainment of the millennium development goals. Food Security, 3, 491-501. https://doi.org/10.1007/s12571-011-0150-3

Khaliq, A., Javed, M., Sohali, M., \& Sagheer, M. (2014). Environmental effects of insects and their population dynamics. Journal of Entomology and Zoology, 2, 1-17.

Khan, Z. R., Pickett, J. A., Wadhams, L., \& Muyekho, F. (2001). Habitat management strategies for the control of cereal stemborers and striga in maize in Kenya. International Journal of Tropical Insect Science, 21, 375-380. https://doi.org/10.1017/S1742758400008481

Kiritani, K. (2013). Different effects of climate change on the population dynamics of insects. Applied Entomology and Zoology, 48, 97-104. https://doi.org/10.1007/s13355-012-0158-y

Li, Z., Zalucki, M. P., Yonow, T., Kriticos, D. J., Bao, H., Chen, H., .. Furlong, M. J. (2016). Population dynamics and management of diamondback moth (Plutella xylostela) in China: The relative contributions of climate, natural enemies and cropping patterns. Bulletin of Entomological Research, 106, 197-214. https://doi.org/10.1017/S0007485315001017

Liebhold, A. M., Work, T. T., McCullough, D. G., \& Cavey, J. F. (2006). Airline baggage as a pathway for alien insect species invading the United States. American Entomology, 52, 48-54. https://doi.org/10.1093/ ae/52.1.48

Luck, J., Spackman, M., Freeman, A., Trebicki, P., Griffiths, W., Finlay, K., \& Chakraborty, S. (2011). Climate change and diseases of food crops. Plant Pathology, 60, 113-121. https://doi.org/10.1111/j.1365-3059. 2010.02414

Macfadyen, S., Mcdonald, G., \& Hill, M. P. (2016). From species distribution to climate change adaptation: knowledge gaps in managing invertebrate pests in broad-acre grain crops. Agriculture, Ecosystems \& Environment (In Press). https://doi.org/10.1016/j.agee.2016.08.029

Machekano, H., Mvumi, B. M., \& Nyamukondiwa, C. (2017). Diamondback moth, Plutella xylostella (L.) in southern Africa: Research trends, challenges and insights on sustainable management options. Sustainability, 9, 1-23. https://doi.org/10.3390/su9020091 
Mampholo, B. M., Sivakumar, D., \& Thompson, A. K. (2016). Maintaining overall quality of fresh traditional leafy vegetables of Southern Africa during the postharvest chain. Food Reviews International, 32, 400-416. https://doi.org/10.1080/87559129.2015.1094817

Maran, A. M., \& Pelini, S. L. (2016). Insect communities. Climate Change (2nd ed., pp. 153-166). Elsevier B.V. http://doi.org/10.1016/B978-0-444-63524-2.00010-5

Mazzi, D., \& Dion, S. (2012). Movement of insect pests in agricultural landscapes. Annals of Applied Biology, 160, 97-113. https://doi.org/10.1111/j.1744-7348.2012.00533.x

Mboup, M., Bahri, B., Leconte, M., De Vallavieille-Pope, C., Kaltz, O., \& Enjalbert, J. (2012). Genetic structure and local adaptation of European wheat yellow rust populations: The role of temperature adaptation. Evolutionary Applications, 5, 341-352. https://doi.org/10.1111/j.1752-4571.2011.00228.x

Meisner, M. H., Harman, J. P., \& Ives, A. R. (2014). Temperature effects on long-term population dynamics in a parasitoid-host system. Ecological Monographs, 84, 457-476. https://doi.org/10.1890/13-1933.1

Mendelsohn, R. (2008). The impact of climate change on agriculture in developing countries. Journal of Natural Resource Policy Research, 1, 5-19. https://doi.org/10.1080/19390450802495882

Mirza, M. M. Q. (2011). Climate change and extreme weather events: Can developing countries adapt? Climate Policy, 3, 233-248. https://doi.org/10.1016/S1469-3062(03)00052-4

Musolin, D. L., Tougou, D., \& Fujisaki, K. (2009). Too hot to handle? Phenological and life history responses to simulated climate change of the southern green stink bug Nezara viridula (Heteroptera: pentatomidae). Global Change Biology, 16, 73-87. https://doi.org/10.1111/j.1365-2486.2009.01914

Newman, J. A. (2003). Climate change and cereal aphids: The relative effects of increasing $\mathrm{CO}_{2}$ and temperature on aphid population dynamics. Global Change Biology, 10, 5-15. https://doi.org/10.1111/j.1365-2486. 2003.00709

Ngowi, A. V., Maeda, D. W., \& Partanen, T. J. (2007). Knowledge, Attitudes and Practices (KAP) among agricultural extension workers concerning the reduction of the adverse impact in agricultural areas in Tanzania. Crop Protection, 26, 1617-1624. https://doi.org/10.1016/j.cropro.2007.01.008

Northstone, K., Joinson, C., Emmett, P., Ness, A., \& Paus, T. (2011). Are dietary patterns in childhood associated with IQ at 8 years of age? A population-based cohort study. Epidemiology and Community Health, 66, 624-628. https://doi.org/10.1136/jech.2010.111955

Nyamukndiwa, C., Weldon, C. W., Chown, S. L., leRoux, P. C., \& Tereblanche, J. S. (2013). Thermal biology, population fluctuations and implications of temperature extremes for the management of two globally significant insect pests. Journal of Insect Physiology, 59, 1199-1211. https://doi.org/10.1016/j.jinsphys. 2013.09.004

Nyirenda, S. P., Sileshi, G. W., Belmain, S. R., Kamanula, J. F., Mvumi, B. M., Sola, P., ... Stevenson, P. C. (2011). Farmers' ethno-ecological knowledge of vegetable pests and pesticidal plant use in Northern Malawi and Eastern Zambia. African Journal of Agricultural Research, 6, 1525-1537. https://doi.org/ 10.5897/AJAR10.498

Nopsa, J. F. H., Thomas-Sharma, S., \& Garrett, K. A. (2014). Climate change and plant disease. Encyclopedia of Agriculture and Food Systems, 2, 232-243.

Olabemiwo, F. A., Danmaliki, G. I., Oyehan, T. A., \& Tawabini, B. S. (2017). Forecasting $\mathrm{CO}_{2}$ emissions in the Persian Gulf States. Global Journal of Environmental Science Management, 3, 1-10. https://doi.org/ 10.22034/gjesm.2017.03.01.001

Obopile, M., Munthali, D. C., \& Matilo, B. (2008). Farmers' knowledge, perceptions and management of vegetable pests and diseases in Botswana. Crop Protection, 27, 1220-1224. https://doi.org/10.1016/ j.cropro.2008.03.003

Ojiewo, C., Keatinge, D. J. D. H., Hughes, J., Tenkouano, A., Nair, R., Varshney, R., ... Silim, S. (2015). The Role of Vegetables and Legumes in Assuring Food, Nutrition, and Income Security for Vulnerable Groups in Sub-Saharan Africa. World Medical \& Health Policy, 7, 3. https://doi.org/10.1002/wmh3.148

Olson, A. J., Pataky, J. K., D’Arcy, C. J., \& Ford, R. E. (1990). Effects of drought stress and infection by Maize dwarf mosaic virus in sweet corn. Plant Disease, 74, 147-151. https://doi.org/10.1094/PD-74-0147 
Palumbo, J. C., \& Natwick, E. T. (2010). The bagrada bug (Hemiptera: Pentatomidae): A new invasive pest of cole crops in Arizonia and Carlifonia. Plant Health Progress. https://oi.org/10.1094/PHP-20100621-01-BR

Paini, D. R., Sheppard, A. W., Cook, D. C., DeBarro, P. J., Worner, S. P., \& Thomas, M. B. (2016). Global threat to agriculture from invasive species. PNAS, 113, 7575-7579. https://doi.org/10.1073/pnas.1602205113

Parmesan, C., \& Yohe, G. (2003). A globally coherent fingerprint of climate change impacts across natural systems. Nature, 421, 37-42. https://doi.org/10.1038/nature01286

Patel, S., Yadar, S. K., \& Singh, C. P. (2017). The incidence of painted bug, Bagrada hilaris (Burmeister) of Brassica spp and Eruca sativa with respect to the date of sowing. Journal of Entomology and Zoology Studies, 5, 774-776.

Pellegrino, A. C., penaflor, M. F. G. V., Nardi, C., Bezner-Kerr, W., Guglielmo, C. G., Bento, J. M. S., \& McNeil, J. N. (2013). Weather forecasting by insects: Modified sexual behaviour in response to atmospheric pressure changes. PLoS ONE, 8, e75004. https://doi.org/10.1371/journal.pone.0075004

Pannga, I. B., Hanan, J., \& Chakraborty, S. (2013). Climate change impacts on plant canopy architecture: Implications for pest and pathogen management. European Journal of Plant Pathology, 135, 596-610. https://doi.org/10.1007/s10658-012-0118-y

Pulatov, B., Hall, K., Anderson, M., \& Jonsson, A. M. (2014). Effect of climate change on the potential spread of the Colorado potato beetle in Scandinavia: An ensemble approach. Inter-Climate Research, 62, $15-24$. https://doi.org/10.3354/cr01259

Reed, D. A., May, C., Lewis, T., \& Perring, T. M. (2011). Effects of temperature and host plant on development, fecundity and longetivity of the stink bug, Bagrada hilaris. Poster presented at the $59^{\text {th }}$ annual meeting of the Entomological Society of America, November 13-16, 2011.

Reed, D. A., Palumbo, J. C., Perring, T. M., \& May, C. (2013). Bagrada hilaris (Hemiptera: Pentatomidae) an invasive stink bug attacking Cole crops in the south-western united States. Journal of Integrated Management, 4, 1-7. https://doi.org/10.1603/IPM13007

Reddy, G. V., Shi, P., Hui, C., Cheng, X., Ouyang, F., \& Ge, F. (2015). The seesaw effect of winter temperature change on the recruitment of cotton bollworms Herlicoverpa amigera through mismatched phenology. Ecology and Evolution, 5, 5652-5661. https://doi.org/10.1002/ece3.1829

Reddy, P. P. (2013). Impact of climate change on insect pests, pathogens and nematodes. Pest Management in Horticultural Ecosystems, 19, 225-233.

Rosenzweig, C., Iglesias, A., Yang, X. B., Epstein, P. R., \& Chivan, E. (2001). Climate change and extreme weather events: Implications for food production, plant diseases and pests. Global Change \& Human Health, 2, 90-104. https://doi.org/10.1023/A:1015086831467

Ryan, G. D., Emiljanowicz, L., Harri, S. A., \& Newman, J. A. (2014). Aphid host-plant genotype $\times$ genotype interactions under elevated $\mathrm{Co}_{2}$. Ecological Entomology, 39, 309-315. https://doi.org/10.1111/een.12101

Saccaggi, D. L., Karsten, M., Robertson, M. P., Kumschick, S., Somers, M. J., Wilson, J. R. U., \& Terblance, J. S. (2016). Methods and approaches for the management of arthropod border incursions. Biological Invasions, 18, 1057. https://doi.org/10.1007/s10530-016-1085-6

Sharma, H. C., \& Prabhaka, C. S. (2014). Impact of climate change on pest management and food security. Integrated pest Management (pp. 23-36). Academic Press, Elsevier, London, UK.

Sparks, T. H., Dennis, R. L. H., Croxtron, P. J., \& Cade, M. (2007). Increased migration of Lepidoptera linked to climate change. European Journal of Entomology, 104, 139-143. https://doi.org/10.14411/eje.2007.019

Singh, H., Malik, V. S. (1993). Biology of painted bug (Bagrada cruciferarum). Indian Journal of Agricultural Science, 63, 672-674.

Sujay, Y. H., Sacatagi, H. N., \& Patil, R. K. (2010). Invasive alien insects and their impact on agroecosystem. Karnataka Journal of Agricultural Sciences, 23, 26-34.

Rejmanek, M., \& Richardson, D. M. (2000). What makes some conifers more invasive? Proceeding of the fourth international conference (In Press).

Tenkouano, A. (2011). The Nutritional and Economic Potential of Vegetables. State of the World's Food and Agriculture 2011: Innovations that Nourish the Planet (pp. 27-38). New York: W. W. Norton \& Company. 
Thompson, S., Levin, S., \& Rodriguez-Iturbe, I. (2013). Linking plant disease risk and precipitation drivers: A dynamical systems framework. The American Naturalist, 181, 1-16. https://doi.org/10.1086/668572

Trebicki, P., Nancarrow, N., Cole, E., Bosque-Perez, N. A., Constable, F. E., Freeman, A. J., ... Fitzgerald, G. J. (2015). Virus disease in wheat predicted to increase with a changing climate. Global Change Biology, 21, 3511-3519. https://doi.org/10.1111/gcb.12941

Uusiku, N. P., Oelofse, A., Duodu, K. G., Bester, M. J., \& Faber, M. (2010). Nutritional value of leafy vegetables of sub-Saharan Africa and their potential contribution to human health: A review. Journal of Food Composition Analysis, 23, 499-509. https://doi.org/10.1016/j.jfca.2010.05.002

Van Averbeke, W., Juma, K. A., \& Tshikalange, T. E. (2007). Yield responses of African leafy vegetables to nitrogen, phosphorus and potassium: The case of Brassica rapa L. Subsp, Chinensis and Solanum retroflexum Dun. Water SA, 33, 355-362. http://dx.doi.org/10.4314/wsa.v33i3.49116

VanDyck, H., Bonte, D., Puls, R., Gotthard, K., \& Maes, D. (2014). The lost generation hypothesis: Could climate change drive ectotherms into a developmental trap? OIKOS Synthesising Ecology, 124, 54-61. https://doi.org/10.1111/oik.02066

Van Jaarsveld, P. J., Faberand, M., \& Van Heerden, I. (2012). Selected vitamin and mineral content of eight African leafy vegetables and their potential contribution to individual nutrient requirements. In A. Oelofse, \& W. Van Averbeke (Eds.), Nutritional Value and Water Use of African Leafy Vegetables for Improved Livelihoods; Water Research Commission TT535/12 (pp. 227-243). Water Research Commission, Pretoria, South Africa.

Vassiliadis, S., Plummer, K. M., Powell, K. S., Trebicki, P., Luck, J. E., \& Rochfort, S. J. (2016). The effect of elevated $\mathrm{CO}_{2}$ and virus infection on the primary metabolism of wheat. Functional Plant Biology, 43, 892-902. https://doi.org/10.1071/FP15242

War, A. R., Paulraj, M. G., Ahmad, T., Buhroo, A. A., Hussain, B., Ignacimuthu, S., \& Sharma, H. C. (2012). Mechanisms of plant defence against insect herbivores. Plant Signal \& Behaviour, 7, 1306-1320. https://doi.org/10.4161/psb.21663

WHO. (2002). World Health Organisation. Nutrition program: Micronutrient deficiency information system, iron deficiency anaemia. Genera, Switzerland. Retrieved from http://www.who.int

WHO. (2013). World Health Organisation global database on vitamin A deficiency. Vitamin and Mineral Nutrition Information System (VMNIS). http://www.who.int/VMNIS/database/vitamin/en

Woodman, J. D. (2015). Surviving a flood: Effects of inundation period, temperature and embryonic development stage in locust eggs. Bulletin of Entomological Research, 105, 441-447. https://doi.org/ $10.1017 / \mathrm{S} 0007485315000243$

Yang, R. Y., \& Keding, G. B. (2009). Nutritional contributions of important African indigenous vegetables. In C. M. Shackleton, C. M., Pasquini, M. W., \& A. W. Drescher (Eds.), African Indigenous Vegetables in Urban Agriculture (Ch. 4, pp. 10-35). Earthscan, London. https://doi.org/10.4324/9781849770019

Zhang, W., Chang, X., Hoffmann, A., Zhang, S., \& Ma, C. (2015). Impact of hot events at different developmental stages of a moth: The closer to adult stage, the less reproductive output. Scientific Reports, 5, 10436. https://doi.org/10.1038/srep10436

Ziska, L. H., \& Mcconnell, L. L. (2016). Climate change, carbon dioxide and pest biology: Monitor, mitigate, manage. Journal of Agricultural and Food Chemistry, 64, 6-12. https://doi.org/10.1021/jf506101h

\section{Copyrights}

Copyright for this article is retained by the author(s), with first publication rights granted to the journal.

This is an open-access article distributed under the terms and conditions of the Creative Commons Attribution license (http://creativecommons.org/licenses/by/4.0/). 